\title{
The Application of QR Code in Improving Participants' Acceptance for Art Works
}

\author{
Dongying Dou \\ Zhuhai College of Jilin University \\ Zhuhai, China 519041
}

\begin{abstract}
With the rapid development of intelligent mobile phone technology, QR Code is used more widely and popularized by mobile phone combined with barcode reader. At the beginning of the study, the comparison of the relevant literature and data shows that the foreign popularity rate of $Q R$ Code technology is far greater than that of our country, especially in the field of art. Although the use of QR Code is very simple, the number of effective QR Codes for auxiliary navigation is very scarce in the field of contemporary art, which causes confusion for visitors to understand the content of art works. After combining the relevant information and the corresponding research methods, this paper has compared respondents with the use of the QR Code reader to assist in understanding the present and contemporary art works. The expected conclusion is that through the intervention of QR Code, the respondents will be more comprehensive and convenient in understanding the content of the works of art. Meanwhile, it will also enhance their ability to study the art works actively, thereby positively affecting their intention on the purchase of relevant art works in the future.
\end{abstract}

Keywords-QR Code; contemporary art; acceptance; purchase intention

\section{INTRODUCTION}

With the rapid development of China's economy and the continuous improvement of people's material level, the demand of the spiritual world is at a stage of rapid growth. As a result of the need for a large amount of private wealth to be reinvested, and the high price of domestic and international art works in auction, more and more art lovers and collectors at home and abroad have paid more attention to art works. Art lovers and collectors are eager to buy contemporary art works with good quality and at low price in the art market full of huge turnover and volume. At the same time, because of the unequal structure of knowledge, the content of most of the works of art, especially contemporary art works, is obscure and unexplained, many collectors who have not enough artistic background and lack of relevant art knowledge will have great obstacles when they want to buy and collect art works. Therefore, how to understand the connotation of contemporary art works quickly and accurately has become a gap that most people cannot overstep.

In today's society with relatively high popularity of smart phones, communication between people is easy and fast, and the dependence of urban people on mobile phones has been reflected in many aspects. Scanning QR Code has become the necessary skill for young people today, and people will use it in many places of life. But in the show of comprehensive data, we can find that in contemporary art works, the intervention of two-dimensional code and the use of it on auxiliary understanding of content information are greatly inferior to those of foreign countries.

Based on the above facts, visitors can use a free network terminal to act as an auxiliary tool for the guide of contemporary art works, which can enable respondents to understand the artistic content of contemporary art works quickly and accurately, and to improve the participants' satisfactory through the intervention and use of QR Code. It also enhances their intension to purchase relevant works of art. The starting point of this paper is to help users relearn the known knowledge by using the QR Code and the purpose is to enhance the students' self-directed learning tendency, multidimensional understanding and analysis of the original problems, so as to expand a known issue to increase the depth and breadth of the answers to the question.

\section{THE BRIEF INTRODUCTION AND CHARACTERISTICS OF QR CODE}

The Quick Response Code (QR Code) is a type of matrix barcode (two-dimensional barcode), which was first appeared as trademark in the Japanese auto industry. The encoded information of QR Code consists of four standardized types of data (numbers, alphanumeric, byte/binary and Kanji), and, of course, it supports almost any type of data by supporting extensions. QR Code is an upgrading version of barcode technology. Initially, as a tracking label for logistics goods, it is gradually being applied to mobile Internet. The emergence of two-dimensional code for mobile greatly reduces social costs and facilitates people's lives. People's behavior habits have further changed. The two-dimensional code has the following characteristics: $a$, the uniqueness of the coding; $b$, the large capacity of information and high-density coding; c, wide range of coding; $d$, the introduced encryption measures; $e$, the high reliability of decoding; $f$, the strong ability of fault tolerance and with the function of error correction; g, low cost, easy to make and durable. 


\section{RESEARCH AND DESIGN}

\section{A. Design of Research Methods}

With a large number of literature research, the author researched the evolution history of two-dimensional code, the characteristics and application of QR Code, the development of modern and contemporary art and the present situation of art market both at home and abroad. On this basis, research cases were selected and analyzed by methods of literature analysis, interdisciplinary research, quantitative analysis and in-depth interview. Finally, the author carried out descriptive statistical analyses of data, the comparative analysis of the difference of learning effectiveness, the overall introspection of the $\mathrm{QR}$ Code guide intervention, and the single factor analysis of variance, and got the final research conclusion.

\section{B. Design of Test Topics}

Part 1: the basic information of respondents: the identity and gender of the respondents, and whether they have used QR Code auxiliary guide.

Part 2: whether respondents use QR Code intervention to make relevant comparisons. Develop topic design through three artists who have made outstanding contributions in the history of Western art; deign three test topics for each artist and gradually increase the difficulty of topic. Meanwhile, the difficulties of the topics about the three artists are also different. Then, the scores of the used group and non-use group in the questionnaire were compared.

Part 3: whether the respondents will have the intention to purchase corresponding contemporary art works after taking part in the art exchange.

There are three types of questionnaires in this study: Q1 Q3 are basic information topics; Q4 Q12 are measured topics; Q13 is a comprehensive topic.

\section{DATA PROCESSING, ANALYSIS AND DisCUSSION}

In the whole questionnaire, the first question divides users of QR Code into two groups. The proportion of the groups is 48 to 52 . At the same time, majors of students participated in are also balanced, and they are not limited to one or two professions. The student users of QR Code and non-users come from four majors (including Chinese, computer, business administration and arts). So, the data obtained are still representative and universal.

In design of issues related to artists, difficulties of topics about each artist are different. In order to confirm whether the intervention of QR Code will have a positive impact on the respondents' understanding of arts, this questionnaire has increased the difficulty of question about the third artist. Only by separating the difficulty of the topic and obtaining the corresponding research data, can we determine whether the QR Code has a corresponding impact on the respondents.

In the last question of the questionnaire, a comprehensive question was designed to determine whether the respondents liked the contemporary art in the whole process of participation. In other words, it is about whether the activity had a positive impact on the respondents, not just the correct answers to the questions of the questionnaire.

Through the use of QR Code, the paper has carried out guide intervention analysis, analysis of $\mathrm{QR}$ Code intervention on complex topics, the effectiveness comparison of QR Code intervention on conventional topics, difference analysis of students users and non-users majoring in arts, difference analysis of students in different gender on learning effectiveness and analysis of purchase intention, and got the conclusion, as shown in "Table I".

TABLE I. The EFFECTIVENESS COMPARISON OF QR CODE

\begin{tabular}{|l|l|l|l|}
\hline & Effective & No Effect & $\begin{array}{c}\text { Not } \\
\text { Obvious }\end{array}$ \\
\hline $\begin{array}{l}\text { The overall effectiveness of the } \\
\text { QR Code guide intervention }\end{array}$ & $\sqrt{ }$ & & \\
\hline $\begin{array}{l}\text { The effectiveness of QR Code } \\
\text { intervention on complex topics }\end{array}$ & $\sqrt{ }$ & & \\
\hline $\begin{array}{l}\text { The effectiveness of QR Code } \\
\text { intervention on conventional } \\
\text { topics }\end{array}$ & $\sqrt{ }$ & & \\
\hline $\begin{array}{l}\text { The effectiveness of QR Code } \\
\text { intervention on students } \\
\text { majoring in art }\end{array}$ & $\sqrt{ }$ & & \\
\hline $\begin{array}{l}\text { The learning effectiveness of } \\
\text { students in different genders } \\
\text { after QR Code intervention }\end{array}$ & & & \\
\hline $\begin{array}{l}\text { The effectiveness of QR Code } \\
\text { intervention on students of arts } \\
\text { and non-art majors }\end{array}$ & $\sqrt{ }$ & & \\
\hline $\begin{array}{l}\text { The effectiveness of using QR } \\
\text { Code on users' intention to } \\
\text { purchase artworks }\end{array}$ & $\sqrt{ }$ & \\
\hline
\end{tabular}

In the data obtained from this survey, we analyzed the users who had scanned QR Code, and most of the users would have the intention to buy the corresponding artwork. This proves that participants who use QR Code will have higher intention to purchase contemporary art works than those who do not use it. In the data obtained, it was clearly shown that the participants at the same professional background were able to understand the content of contemporary art works with the QR Code better than those who did not use it. At the same time, the intervention of QR Code improves testers' understanding ability, and their intention to purchase corresponding artworks. The data also showed that testers who used QR Code were much more willing to buy contemporary art than those who did not use it, with a proportion of 83 to 50 . Therefore, it can be determined that the intervention of $\mathrm{QR}$ Code has played a positive role in understanding the connotation of contemporary art and the intention to purchase the corresponding art. 


\section{CONCLUSION}

Through the above analysis, the students participating in the test are very effective in learning contemporary art with the intervention of QR Code to assist. It can not only enhance students' active participation in contemporary art, but also increase their subjective interaction with works of art.

Because a large number of image processing recognition and error correction recognition are designed in the QR Code recognition algorithm, the implementation of this recognition method determines the performance of the whole QR Code system to a great extent. Because the program runs on the embedded equipment with very limited computing power, its performance constraints are more stringent, and it has relatively high requirements for the corresponding time of the program and the speed of QR Code image information recognition. At the same time, it is also emphasized that the program must not be able to leak memory, otherwise it will lead to the collapse of the mobile phone operating system on the embedded device. In this study, the paper only used quantitative analysis and files collection and other research methods to study the research object, and do not do in-depth interviews and case studies for individuals.

For the 100 students who participated in the test, no one of the group was investigated in depth. At the same time, due to the influence of time, manpower, material and other related factors, the results obtained are not completely universal, so it is hoped that the follow-up researchers can expand the scope of research and collect more historical documents under the circumstances of many factors. In the content of the study, more valuable contemporary artists and contemporary art works can be added, and the scope is not only limited to the art of painting on the shelf, but also the installation art and behavior art at the same period. The content of the questionnaire can be enriched, and other relevant artistic forms can be added to the questionnaire, and more valuable problems with reference can be raised on the topic of the questionnaire, and it can also be increased in quantity.

Through this study, it is found that the advantages of this thesis are more obvious in topic selection. Most people will not notice the combination field of $\mathrm{QR}$ Code and art. This innovative topic is quite difficult in the study, not only because it has much interdisciplinary knowledge, but also it requires researchers to be very familiar with and understand the knowledge of relevant disciplines. So, in the whole research, the information that can be learned and used is not very rich. In the subject of art, contemporary art is an art class which is difficult to understand and not easy to popularize. It also requires more professional knowledge. This requires me to reflect the difference between contemporary art and traditional art in the selection of the questionnaire. However, due to the consistent development of art history, all contemporary arts have been derived from traditional art. So, three questions were set up about one contemporary artist, and they are of three different difficulties. Thus, it can also reflect the evolution process of the artist himself from tradition to innovation.

Not only that, the three artists the paper selected are all the representative figures in their own field, and the difficulty setting is also gradually increasing from the first artist to the last artist. So, in the final test of the last artist (Mark Roscoe), the number of respondents with all correct answers about the last artist was not more than that of respondents about the first artist (Mondrian). It can be seen that although different difficult test topics were set up in the questionnaire consciously, the purpose is to get the relatively clear research data. In selection of the artists in this questionnaire, they should be relatively popular and easier to be accepted as well as their art works, so that respondents could answer the questions correctly and truly reflect using experiences. The first-time feedback effect could be better.

\section{REFERENCES}

[1] He Binkang (2015). Research on Secure Storage System based on Cloud Storage Environment. Information Construction, Hubei. 贺斌慷 （2015）。基于云存储环境的安全存储系统研究。信息化建设, 湖 北

[2] Ge Huanyu (2012). Characteristics of Matisse Art. Literary and Artistic Life, Literature and Art Theory, Qingdao. 葛环玉（2012）。 Characteristics of Matisse art。文艺生活·文艺理论, 青岛

[3] Hu Pingwang, Huang Ronggui, Gu Keqing (2002). Application of Twodimensional Code Vehicle Information Management System. Traffic and Computer, Bengbu. 胡平旺,黄荣贵,顾克庆 (2002)。二维码车 辆信息管理系统应用研究。交通与计算机, 蚌埠

[4] Li Na, Huang Xiaobin, Li Qin, Jiang Pan (2010). Comparative Overview Library to Data Mining Software Product. Volkswagen Science and Technology, Beijing. 李娜, 黄孝涁, 李琴, 姜攀(2010)。数 据挖掘软件产品综述对比库。大众科技, 北京

[5] Lin Tingsheng (2011). Discussion on the Effectiveness of Action Guidance System: Taking campus public art as an example. National Tsinghua University, Hsinchu. 林庭偢（2011）。行动导览系统成效 探讨: 以校园公共艺术为例。国立清华大学, 新竹市

[6] Qi Jinyue (2004). Research on the Generation and Recognition of Twodimensional Barcode. Master's Thesis of Harbin Engineering University, Harbin. 齐金月（2004）。二维条形码的生成与识别研究。哈尔滨 工程大学硕士论文, 哈尔滨

[7] Shi Junfei (2013). Design and Implementation of QR Code Recognition System. Master's Thesis of University of Electronic Science and Technology, Chengdu. 师俊飞（2013）。QR Code 识别系统的设计 与实现。电子科技大学硕士论文, 成都

[8] Sun Quan (2015). Non-contact Interbank Withdrawals System based on Security of Two-dimensional Code. Software Industry and Engineering, Shanghai.孙权（2015）。一种基于二维码的安全非接触式跨行取款 系统。软件产业与工程, 上海

[9] Shen Lin (2014). The Influence of the Use of Two-dimensional code of Mobile Phone. Nanjing Arts Institute. 申林 (2014)。手机二维码使 用的影响初探。南京艺术学院 